\title{
Effect of cold stress on immunity in rats
}

\author{
GUO-ZHU HU ${ }^{1}$, SI-JUN YANG ${ }^{2}$, WEI-XU HU ${ }^{3}$, ZHU WEN $^{4}$, DAN HE ${ }^{1}$, LI-FENG ZENG ${ }^{1}$, \\ QIN XIANG $^{5},{\mathrm{XIAO}-\mathrm{MU} \mathrm{WU}^{1}, \mathrm{WEN}^{-} \mathrm{YUN}_{\mathrm{ZHOU}}{ }^{1} \text { and QING-XIAN ZHU }}^{6}$ \\ ${ }^{1}$ Institute of Clinical Medical Sciences, Jiangxi Province People's Hospital; ${ }^{2}$ Graduate Student Department, \\ Medical College of Nanchang University, Nanchang, Jiangxi 330006; ${ }^{3}$ Department of Radiation Oncology, \\ Zhongshan Hospital, Fudan University, Shanghai 200032; ${ }^{4}$ Department of Hematology, \\ Jiangxi Academy of Medical Science, Nanchang, Jiangxi 330006; ${ }^{5}$ College of Biology, \\ Hunan University, Changsha, Hunan 410082; ${ }^{6}$ Department of Histoembryology, \\ Medical College of Nanchang University, Nanchang, Jiangxi 330006, P.R. China
}

Received June 2, 2014; Accepted February 4, 2015

DOI: $10.3892 / \mathrm{etm} .2015 .2854$

\begin{abstract}
An increase in the morbidity of upper respiratory tract infections and the attack and exacerbation of autoimmune diseases has been observed to occur in the few days following sudden environmental temperature decreases, but the mechanisms for these phenomena are not well understood. To determine the effect of a sudden ambient temperature drop on the levels of stress hormones and T-lymphocyte cytokines in the plasma, the Toll-like receptor 4 (TLR4) expression of immunocompetent cells in rat spleens and the levels of regulatory $\mathrm{T}$ (Treg) cells in the peripheral blood, Sprague Dawley rats were divided into three groups of different ambient temperatures $\left(20,4\right.$ and $\left.-12^{\circ} \mathrm{C}\right)$. In each group, there were four observation time-points $(1,12,24$ and 48 h). Each ambient temperature group was subdivided into non-stimulation, lipopolysaccharide-stimulation and concanavalin A-stimulation groups. The levels of adrenocorticotropin (ACTH), epinephrine (EPI), angiotensin-II (ANG-II), interleukin-2 (IL-2), interferon- $\gamma($ IFN- $\gamma)$, IL-4 and IL-10 in the plasma were determined using ELISA. The cellular expression levels of TLR4 and the presence of cluster of differentiation (CD) $4^{+} \mathrm{CD} 25^{+}$ and $\mathrm{CD} 4{ }^{+} \mathrm{CD} 25^{+}$Forkhead box $\mathrm{P} 3$ (Foxp3) ${ }^{+}$cells were determined using flow cytometry. The experiments demonstrated that the ACTH, EPI, ANG-II and IL-10 levels in the plasma were significantly increased at 4 and $-12^{\circ} \mathrm{C}$ compared with those at $20^{\circ} \mathrm{C}$, while the plasma levels of IFN- $\gamma$, IL-2 and IL-4, the TLR4 expression rates of immunocompetent cells in the rat spleen and the percentage of $\mathrm{CD} 4^{+} \mathrm{CD} 25^{+} \mathrm{Foxp} 3^{+}$Treg cells among the $\mathrm{CD} 4{ }^{+} \mathrm{CD} 25^{+}$Treg cells in the peripheral blood were
\end{abstract}

Correspondence to: Professor Qing-Xian Zhu, Department of Histoembryology, Medical College of Nanchang University, $461 \mathrm{Ba}$ Yi Road, Nanchang, Jiangxi 330006, P.R. China E-mail: hgz56@126.com

Key words: ambient temperature, cold stress, hormones, peripheral blood, rat, spleen, Toll-like receptor 4, regulatory T cells decreased at 4 and $-12^{\circ} \mathrm{C}$ compared with those at $20^{\circ} \mathrm{C}$. These data indicate that cold stress affects the stress hormones and the innate and adaptive immunity functions in rats.

\section{Introduction}

A sudden increase in the morbidity of upper respiratory tract infections (1) and the attack and exacerbation of autoimmune diseases (2) have been observed in the few days following sudden environmental temperature decreases. Cold stress has been reported to suppress host innate immune defenses. Macrophages from mice subjected to $10 \mathrm{~min}$ of cold stress $\left(a t-15^{\circ} \mathrm{C}\right.$ ) exhibited a lower phagocytic capacity than cells from control animals, and corticosterone affected phagocytosis by macrophages (3). TLR4 (Toll-like receptor 4) is a pattern recognition receptor of pathogen-associated molecular patterns. It has been shown that TLR4 mutant mice are more susceptible to pulmonary tuberculosis and enhanced mycobacterial outgrowth (4). Levels of cluster of differentiation (CD) $3^{+}(\mathrm{CD} 4$ and CD8) T cells have been found to be reduced following acute cold restraint stress, and the T-cell lymphopenia was mediated predominantly through a $\beta 2$-adrenergic receptor mechanism (5). Cold exposure $\left(-5^{\circ} \mathrm{C}\right)$ has been shown to increase the delayed-type hypersensitivity (DTH) reaction by $42 \%$ in calves after one week (6), and serum interleukin-2 (IL-2) levels have been found to be reduced in rats immersed in cold water for $30 \mathrm{~min}$ (7). Cold stress also affects the host adaptive immune system.

The serum adrenocorticotropin (ACTH), epinephrine (EPI) and angiotensin II (ANG-II) levels have been demonstrated to be significantly higher in mice and rats exposed to the cold compared with those in normal-temperature control group animals (8-11). Cold stress induces an increase in ANG-II and supports a sympathetic-mediated stress response through stimulation of angiotensin receptor 1 [AT(1)] in humans (12).

In order to confirm whether the sudden environmental temperature drop decreases immunity in mammals, the aim of the present study was to observe the effect of sudden cold stress on the ACTH, EPI, ANG- II, interferon- $\gamma$ (IFN- $\gamma$ ), IL-2, IL-4 and IL-10 levels in the plasma, the TLR4 expression of immunocompetent cells in the spleen and the regulatory $\mathrm{T}$ (Treg) cell 
expression in the peripheral blood in rats. Investigations of this type may provide insight that would aid with disease prevention following sudden environmental temperature decreases.

\section{Materials and methods}

Study groups. A total of 252 Sprague Dawley (SD) rats were purchased from Shanghai Xi Pu Er-Bi Kai Experimental Animal Co., Ltd. (Shanghai, China) (certification no. 00800161082; license no. SCXK (Shanghai) 2008-0016). The rats had a mean weight of $275.24 \pm 35.73 \mathrm{~g}$ (range, 198-378 g), were aged 9-15 weeks and were housed under a 12-h light/dark cycle with free access to food and water, were included in the present study. Following adaptation for seven days at $20^{\circ} \mathrm{C}$, the rats were divided into 20,4 and $-12^{\circ} \mathrm{C}$ groups. In each temperature group, there were four observation time-points (1, 12, 24 and $48 \mathrm{~h}$ ), and each time group was further subdivided into non-stimulation, lipopolysaccharide (LPS)-stimulation and concanavalin A (Con-A)-stimulation groups. The body's response to bacterial invasion was investigated by LPS-stimulation, and the response to viral invasion was investigated by Con-A-stimulation. The rats in the $20^{\circ} \mathrm{C}$ group were kept in the natural environment while the rats in the 4 and $-12^{\circ} \mathrm{C}$ groups were maintained in low-temperature climate incubators (model RXZ-0450; Ningbo Southeast Instrument Co., Ltd., Ningbo, China). The rats were given ad libitum access to food in all of the groups; however, with regards to water, the rats in the 12,24 and $48 \mathrm{~h}$ groups were given constant ad libitum access, whereas the $-12^{\circ} \mathrm{C}$ group were given free access at three specific time points per day. One rat was placed in each cage. The environmental humidity was $50 \%$. The experimental studies with the rats were performed in accordance with the Animal Experiment Guidelines established by The Ministry of Science and Technology of the People's Republic of China. The animal experiments in this paper were approved by Jiangxi Province People's Hospital Ethics Committee (Nanchang, China).

LPS and Con-A stimulation. Following adaptation for seven days at $20^{\circ} \mathrm{C}$, LPS $(1.0 \mathrm{mg} / \mathrm{kg}$ body weight; from Escherichia coli 055:B5; cat. no. L2880; Sigma-Aldrich, St. Louis, MO, USA) or Con-A [5.0 mg/kg body weight; from Canavalia ensiformis (Jack bean) Type IV; cat. no. C2010-1G; Sigma-Aldrich] were administered to the SD rats once via intraperitoneal injection. The rats were then placed in the natural environment $\left(20^{\circ} \mathrm{C}\right)$ or the 4 and $-12^{\circ} \mathrm{C}$ environment cabinets for 1, 12, 24 and $48 \mathrm{~h}$.

Spleen mononuclear cell (MNC) suspension preparation. The rats were anesthetized by pentobarbital sodium via intraperitoneal injection, prior to the removal of the spleen. The cell suspension was prepared by grinding the spleen with $1.0 \%$ fetal calf serum (FCS) (Zhejiang Tianhang Biotechnology Co., Ltd., Hangzhou, China), $0.03 \% \mathrm{NaN}_{3}$ (Binhai Hanhong Biochemical Co., Ltd., Shanghai, China) and $0.01 \mathrm{M}$ phosphate-buffered saline (PBS) (Beijing Solarbio Science \& Technology Co., Ltd., Beijing, China) (pH 7.4) and filtering through 200-mesh stainless steel nets. The MNCs were separated by Ficoll-Hypaque (Tianjin Hao Yang Biological Manufacture Co., Ltd., Tianjin, China) density gradient centrifugation and washed two times in $1.0 \%$ FCS, $0.03 \% \mathrm{NaN}_{3}$ and $0.01 \mathrm{M} \mathrm{PBS}$ via centrifugation at $400 \mathrm{x} \mathrm{g}$ for $10 \mathrm{~min}$ at $4^{\circ} \mathrm{C}$ (Allegra ${ }^{\mathrm{TM}}$ 6R, Beckman Coulter, Miami, FL, USA) for $10 \mathrm{~min}$. The cell concentration was then adjusted to $1 \times 10^{7} / \mathrm{ml}$.

\section{Fluorescence staining and detection}

TLR4 expression of MNCs. A total of $10 \mu 1$ mouse monoclonal anti-TLR4-phycoerythrin (PE) antibody $(1.0 \mu \mathrm{g} / 10 \mu \mathrm{l}$; cat. no. ab45104 Abcam, Hong Kong SAR, China) was added to the bottom of a plastic tube; as a control, $5 \mu 1$ isotype control antibody [mouse monoclonal isotype control PE immunoglobulin G (IgG)2b к; cat. no. 12-4732 eBioscience, Inc., San Diego, CA, USA] was added to another tube. A total of $5 \times 10^{5} \mathrm{MNCs} / 50 \mu 1$ was then added to each tube, and the tubes were vortexed and placed at room temperature, avoiding the light, for $40 \mathrm{~min}$. PBS ( $2 \mathrm{ml})$ was added to each tube, and the mixture was washed with PBS two times via centrifugation $\left(400 \mathrm{x} \mathrm{g}, 5 \mathrm{~min}, 4^{\circ} \mathrm{C}\right)$. Following centrifugation, $0.4 \mathrm{ml}$ flow cytometric sheath fluid was added to each tube, and TLR $4^{+}$cells were detected using a flow cytometer (Coulter Epics XL; Beckman Coulter). The voltage was adjusted with the naked cells, and $>30,000$ cells were counted in each tube.

Treg cell detection in the peripheral blood. A total of $5 \mu \mathrm{l}$ mouse monoclonal anti-rat CD25-PE $(0.125 \mu \mathrm{g} / 5 \mu \mathrm{l}$; cat. no. 12-0390; eBioscience, Inc.) and $5.0 \mu 1$ mouse monoclonal PE-cyanine 5 (Cy5)-conjugated anti-rat CD4 $(0.25 \mu \mathrm{g} / 5 \mu \mathrm{l}$; cat. no. 554839; BD Pharmingen, San Diego, CA, USA) antibodies were added to the bottom of a plastic tube, and $5.0 \mu 1$ mouse monoclonal isotype control IgG1к-PE (cat. no. 12-4714; eBioscience, Inc.) and $5.0 \mu 1$ mouse monoclonal isotype control IgG2a $\kappa-\mathrm{PE}-\mathrm{Cy} 5$ (cat. no. 15-4724; eBioscience, Inc.) antibodies were added to another tube. In addition, $50 \mu 1$ EDTA-anticoagulated rat peripheral blood and $50 \mu \mathrm{l}$ PBS were added to each tube; the tubes were then vortexed and placed at room temperature, avoiding the light, for $60 \mathrm{~min}$. After $60 \mathrm{~min}, 0.2 \mathrm{ml}$ red blood cell lysing solution (OptiLyse ${ }^{\circledR}$ C, Beckman Coulter) was added to each tube for incubation at room temperature for $13 \mathrm{~min}$. Following incubation, the tubes were washed two times with $2 \mathrm{ml}$ PBS via centrifugation $\left(400 \mathrm{x} \mathrm{g}, 10 \mathrm{~min}, 5^{\circ} \mathrm{C}\right)$. The supernatant was then removed, and $1.0 \mathrm{ml} 1 \mathrm{X}$ fixation/permeabilization solution [Forkhead box P3 (Foxp3) Fixation/Permeabilization Concentrate and Diluent; eBioscience, Inc.] was added to each tube, which was vortexed and incubated at $4^{\circ} \mathrm{C}$, avoiding the light, for $60 \mathrm{~min}$. Following incubation, $1 \mathrm{X}$ permeabilization buffer solution (10X Permeabilization Buffer; eBioscience, Inc.) was added to each tube, and the tubes were vortexed and washed two times via centrifugation $(400 \mathrm{x} \mathrm{g}, 10 \mathrm{~min}$, $5^{\circ} \mathrm{C}$ ). The supernatant was subsequently removed, and $5.0 \mu \mathrm{l}$ monoclonal fluorescein isothiocyanate (FITC)-anti-rat Foxp3 antibody (cat. no. 11-5773; eBioscience, Inc.) was added to the $\mathrm{CD} 4{ }^{+} \mathrm{CD} 25^{+}$tube, while $5.0 \mu 1$ monoclonal FITC-rat IgG2a isotype control antibody (cat. no. 11-4321; eBioscience, Inc.) was added to the isotype control tube. The tubes were then vortexed and incubated at $4^{\circ} \mathrm{C}$, avoiding the light, for $60 \mathrm{~min}$. After $60 \mathrm{~min}, 1.0 \mathrm{ml}$ 1X permeabilization buffer was added, and the tubes were vortexed and washed two times via centrifugation $\left(400 \mathrm{x} \mathrm{g}, 10 \mathrm{~min}, 5^{\circ} \mathrm{C}\right)$. Following 
centrifugation, $0.4 \mathrm{ml}$ flow cytometric sheath fluid was added to each tube and the tubes were vortexed, prior to the tube contents being analyzed using a flow cytometer (Coulter Epics XL; Beckman Coulter). The voltage was adjusted with the naked cells, and $>30,000$ cells were counted in each tube. The $\mathrm{CD} 4{ }^{+} \mathrm{CD} 25^{+}$cells were initially measured and counted, and then the Foxp $3^{+}$cells among the $\mathrm{CD} 4^{+} \mathrm{CD} 25^{+}$cells were measured and counted.

Hormone and cytokine assay. The ACTH, EPI, ANG-II, IFN- $\gamma$, IL-2, IL-4 and IL-10 levels in the plasma were determined via sandwich ELISA using ELISA kits from Shanghai Westang Bio-Tech Co., Ltd. (Shanghai, China) and a Multiskan Ascent ${ }^{\circledR}$ instrument (Thermo Fisher Scientific, Inc., Waltham, MA, USA). The procedure was performed according to the ELISA kit specifications.

Statistical analysis. The experimental data are expressed as the mean \pm standard deviation. Data analysis was performed using SPSS 16.0 statistical software (SPSS, Inc., Chicago, IL, USA) with multi-way univariate analysis of variance and Levene's test for equality of error variances, and then post hoc tests were used for comparison between two groups. $\mathrm{P}<0.05$ was considered to indicate a statistically significant difference.

\section{Results}

Effect of different temperatures and stimulants on levels of stress hormones in the rat plasma. The mean levels of ACTH, EPI and ANG-II were compared at different times, temperatures, and in response to various stimulants (Figs. 1 and 2). Compared with the results at $20^{\circ} \mathrm{C}$, the level of ACTH in the rat plasma was increased at the 1-48-h time-points in the 4 and $-12^{\circ} \mathrm{C}$ non-stimulation groups; at the $1-48-\mathrm{h}$ time-points at $4^{\circ} \mathrm{C}$ and at the $1-24$-h time-points at $-12^{\circ} \mathrm{C}$ in the LPS-stimulation group; and at the 1-48-h time-points in the $-12^{\circ} \mathrm{C}$ Con-A-stimulation group (Figs. 1A and $\mathrm{B}$ and $2 \mathrm{~A})$. With regard to EPI levels, comparisons with the values at $20^{\circ} \mathrm{C}$ revealed increases in the $4^{\circ} \mathrm{C}$ and $-12^{\circ} \mathrm{C}$ non-stimulation groups at the 1-48-h time-points, in the $4^{\circ} \mathrm{C}$ LPS-stimulation group at the 1-48-h time-points, in the $-12^{\circ} \mathrm{C}$ LPS-stimulation group at the 1-24-h time-points, in the $4^{\circ} \mathrm{C}$ Con-A-stimulation group at the 1-12-h time-points and in the $-12^{\circ} \mathrm{C}$ Con-A-stimulation group at 1,12 and $48 \mathrm{~h}$ (Figs. $1 \mathrm{C}$ and $\mathrm{D}$ and $2 \mathrm{~B}$ ). Compared with the results at $20^{\circ} \mathrm{C}$, the level of ANG-II in the rat plasma was increased in the $4^{\circ} \mathrm{C}$ and $-12^{\circ} \mathrm{C}$ non-stimulation and LPS-stimulation groups at the 1-48-h time-points, in the $4^{\circ} \mathrm{C}$ Con-A-stimulation group at $1 \mathrm{~h}$ and in the $-12^{\circ} \mathrm{C}$ Con-A-stimulation group at the $1-48-\mathrm{h}$ time-points (Figs. 1E and $\mathrm{F}$ and $2 \mathrm{C}$ ).

In summary, it was found in the present study that the levels of ACTH, EPI and ANG-II in the rat plasma were increased following cold stress, which was consistent with the results described by Ablimit et al (8), Belay and Woart (9), Vernikos et al (10), Yang et al (11) and Israel et al (12). The data suggest that cold stress activates the hypothalamic-pituitary-adrenocortical (HPA) axis (ACTH), the adrenomedullary hormonal system (AHS) (EPI) and the renin-angiotensin-aldosterone system (RAAS) (ANG-II), which may suppress the immunity of rats.
Effect of different temperatures and stimulants on levels of T-lymphocyte cytokines in the rat plasma. The mean levels of IL-2, IL-4, IFN- $\gamma$ and IL-10 were compared at different times, temperatures, and in response to various stimulants (Figs. 3 and 4). Compared with the values at $20^{\circ} \mathrm{C}$, the level of IL-2 in the rat plasma was decreased at $24 \mathrm{~h}$ in the $4^{\circ} \mathrm{C}$ non-stimulation and LPS-stimulation groups, at the 24-48-h time-points in the $-12^{\circ} \mathrm{C}$ non-stimulation and LPS-stimulation groups, at the 1-48-h time-points in the $4^{\circ} \mathrm{C}$ Con-A-stimulation group and at the $12-48$-h time-points in the $-12^{\circ} \mathrm{C}$ Con-A-stimulation group (Figs. 3A and $\mathrm{B}$ and $4 \mathrm{~A}$ ). With regard to the level of IL-4 in the rat plasma, comparisons with the results at $20^{\circ} \mathrm{C}$ revealed decreases at the 12-48-h time-points in the 4 and $-12^{\circ} \mathrm{C}$ non-stimulation and LPS-stimulation groups, at the 1-24-h time-points in the $4^{\circ} \mathrm{C}$ Con-A-stimulation group and at $12 \mathrm{~h}$ in the $-12^{\circ} \mathrm{C}$ Con-A-stimulation group (Figs. $3 \mathrm{C}$ and D and $4 \mathrm{~B}$ ). The level of IFN- $\gamma$ in the rat plasma was decreased at the 12-24-h time-points in the $4^{\circ} \mathrm{C}$ non-stimulation and LPS-stimulation groups, at 1,24 and $48 \mathrm{~h}$ in the $-12^{\circ} \mathrm{C}$ non-stimulation and LPS-stimulation groups, at the 12-24-h time-points in the $4^{\circ} \mathrm{C}$ Con-A-stimulation group and at the $1-12$-h time-points in the $-12^{\circ} \mathrm{C}$ Con-A-stimulation group compared with the results at $20^{\circ} \mathrm{C}$ (Figs. $3 \mathrm{E}$ and $\mathrm{F}$ and $4 \mathrm{C}$ ). By contrast, the level of IL-10 in the rat plasma was increased at the $1-48$-h time-points in the 4 and $-12^{\circ} \mathrm{C}$ non-stimulation and LPS-stimulation groups and at the 1-48-h time-points in the $-12^{\circ} \mathrm{C}$ Con-A-stimulation group compared with the values at $20^{\circ} \mathrm{C}$ (Figs. $3 \mathrm{G}$ and $\mathrm{H}$ and $4 \mathrm{D}$ ).

In summary, it was found in the present study that the levels of IL-2, IL-4 and IFN- $\gamma$ in the rat plasma were decreased and the level of IL-10 in the rat plasma was increased following cold stress; these immunosuppressive states were not improved using LPS and Con-A stimulation. These results were similar to those described by Liu et al (7), Belay and Woart (9), Shu et al (13) and Aviles and Monroy (14). The data suggest that rats are induced to a state of autoimmune response by cold stress.

Effect of different temperatures and stimulants on the expression of $T L R 4^{+} M N C s$ in the rat spleen. The mean levels of TLR4 ${ }^{+}$MNCs in the spleen were compared at different times, temperatures, and in response to various stimulants (Figs. 5 and 6). Compared with the results at $20^{\circ} \mathrm{C}$, the levels of TLR4 ${ }^{+}$MNCs in the spleen were decreased at 12 and $48 \mathrm{~h}$ in the $4^{\circ} \mathrm{C}$ non-stimulation group, at 1,12 and $48 \mathrm{~h}$ in the $-12^{\circ} \mathrm{C}$ non-stimulation group, at the $12-48$-h time-points in the $4^{\circ} \mathrm{C}$ LPS-stimulation group, at the 1-48-h time-points in the $-12^{\circ} \mathrm{C}$ LPS-stimulation group and at 1,12 and $48 \mathrm{~h}$ in the 4 and $-12^{\circ} \mathrm{C}$ Con-A-stimulation groups (Figs. 5A and B and $6 \mathrm{~A})$. Greater temperature decreases resulted in more evident decreases in the TLR4 expression rate. These data demonstrate that TLR4 expression in immunocompetent cells in the spleen was decreased when EPI and IL-10 expression increased, and that the innate immunity function in rats was damaged following cold stress.

In summary, the results of the present study showed that the TLR4 expression rates in the MNCs in the rat spleen were decreased following cold stress, and were not improved by LPS and Con-A stimulation. This suggests that the innate immunity of rats is suppressed by cold stress; consistently, 


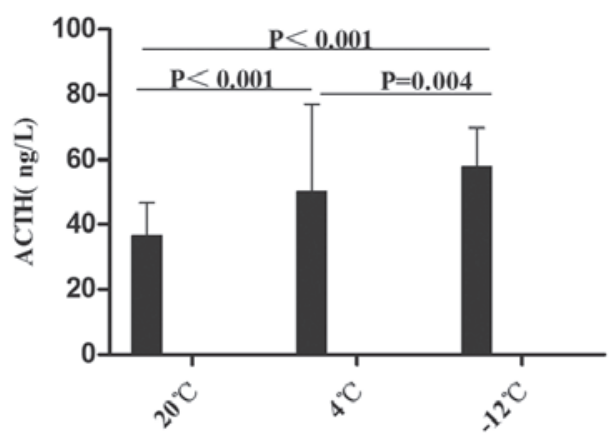

C

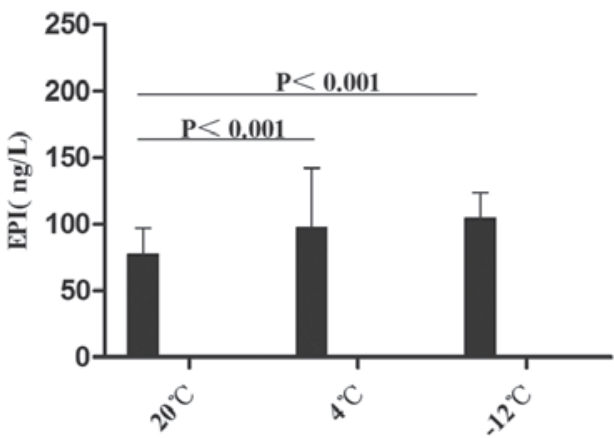

$\mathbf{E}$

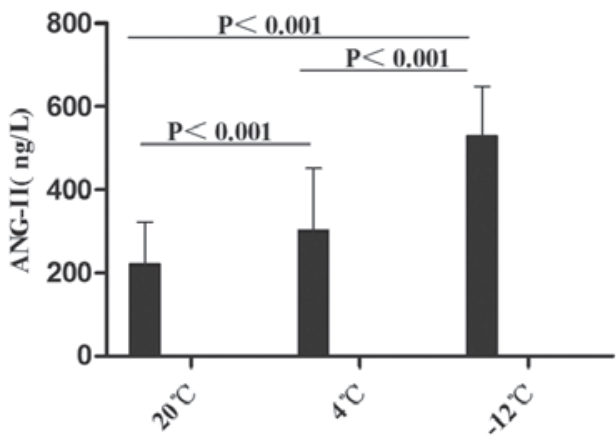

B

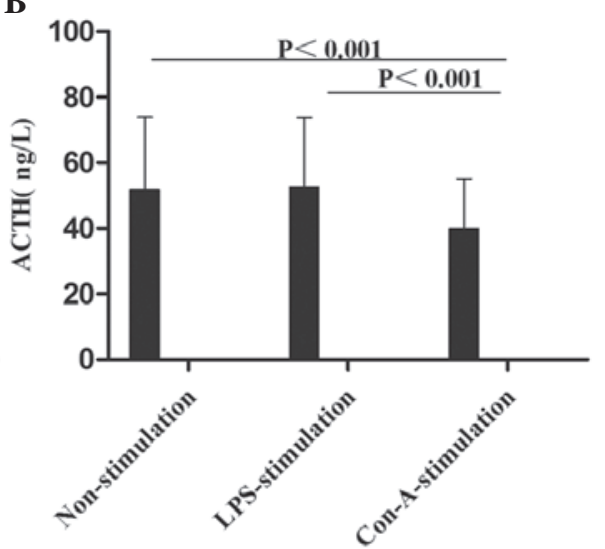

D

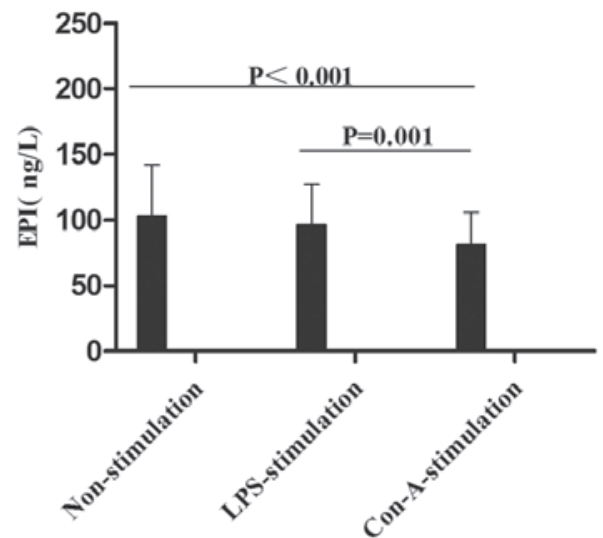

$\mathbf{F}$

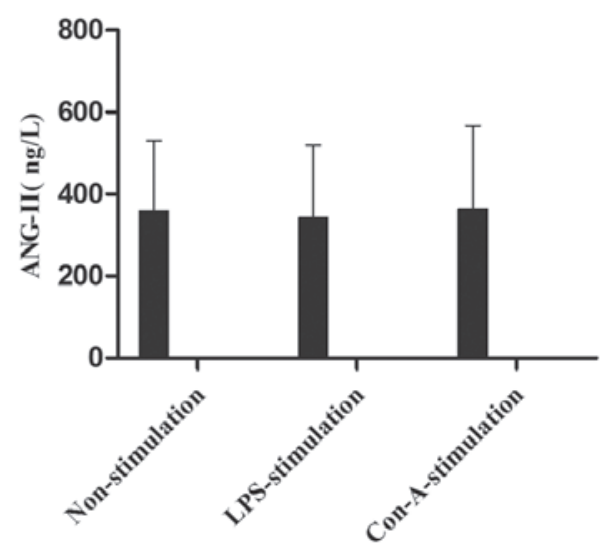

Figure 1. Comparison of the mean levels of (A and B) ACTH, (C and D) EPI and (E and F) ANG-II in the plasma at different temperatures and with different stimulants. Data are presented in $\mathrm{ng} / \mathrm{l}$ as the mean \pm standard deviation. (A and B) Analysis of the ACTH data revealed the following: Comparison among multiple temperatures, $\mathrm{F}(2,230)=28.714, \mathrm{P}<0.001$; comparison among multiple stimulants, $\mathrm{F}(2,230)=10.864, \mathrm{P}<0.001$; comparison between temperatures and stimulants, $\mathrm{F}(4,230)=6.652, \mathrm{P}<0.001$. (C and D) Analysis of the EPI data revealed the following: Comparison among multiple temperatures, $\mathrm{F}(2,215)=20.685$, $\mathrm{P}<0.001$; comparison among multiple stimulants, $\mathrm{F}(2,215)=8.663, \mathrm{P}<0.001$; comparison between temperatures and stimulants, $\mathrm{F}(4,215)=6.195, \mathrm{P}<0.001$. (E and F) Analysis of the ANG-II data revealed the following: Comparison among multiple temperatures, F $(2,213)=150.164$, $\mathrm{P}<0.001$; comparison between temperatures and stimulants: F $(4,213)=5.971, \mathrm{P}<0.001$. ACTH, adrenocorticotropin; EPI, epinephrine; ANG-II, angiotensin-II; LPS, lipopolysaccharide; Con-A, concanavalin A.

TLR4 mutant mice have been shown to be more susceptible to pulmonary tuberculosis and enhanced mycobacterial outgrowth (4).

Effect of different temperatures and stimulants on Treg cells in the peripheral blood in rats. The mean levels of $\mathrm{CD} 4^{+} \mathrm{CD} 25^{+}$ and $\mathrm{CD} 4{ }^{+} \mathrm{CD} 25^{+} \mathrm{Foxp}^{+}$Treg cells in the peripheral blood were compared at different times, temperatures, and in response to various stimulants (Figs. 5 and 6 ). $\mathrm{CD} 4^{+} \mathrm{CD} 25^{+}$ Treg cell rates in the peripheral blood were decreased at the 1-48-h time-points at $4^{\circ} \mathrm{C}$ and at the 12-48-h time-points at $-12^{\circ} \mathrm{C}$ in the non-stimulation group; at the $12-48$-h time-points in the $-12^{\circ} \mathrm{C}$ LPS-stimulation group; and at $1 \mathrm{~h}$ in the $-12^{\circ} \mathrm{C}$ Con-A-stimulation group, compared with the results at $20^{\circ} \mathrm{C}$ (Figs. 5C and D and 6B). With regard to the percentage of $\mathrm{CD} 4{ }^{+} \mathrm{CD} 25^{+} \mathrm{Foxp}^{+}{ }^{+}$Treg cells, significant decreases were 

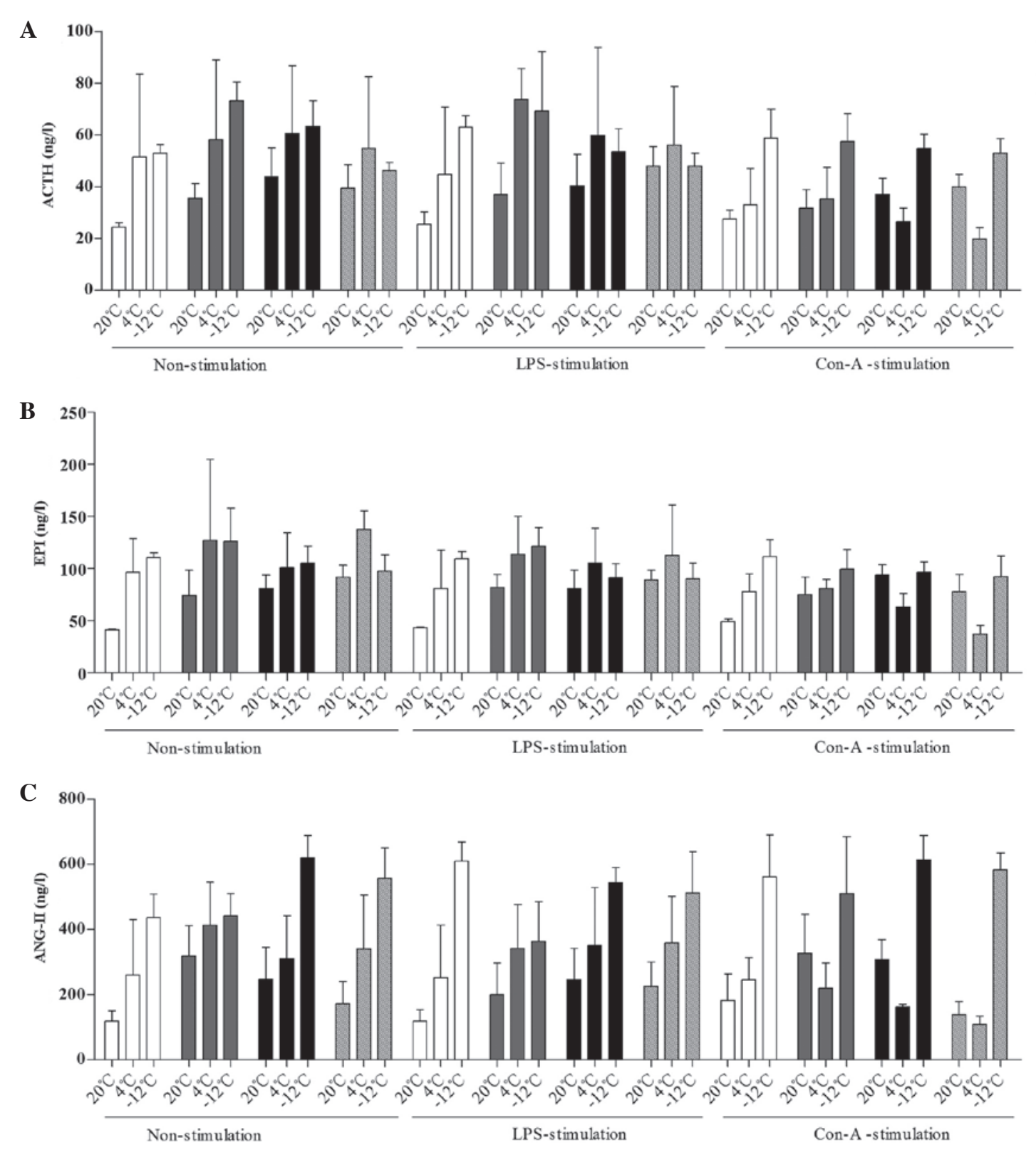

Figure 2. Comparison of the mean levels of (A) ACTH, (B) EPI and (C) ANG-II in the plasma at different times, temperatures and with different stimulants. Data are presented in $n g / 1$ as the mean \pm standard deviation. (A) For the comparison of the ACTH data among multiple times: $F(3,230)=3.743$, $\mathrm{P}=0.012$; $1 \mathrm{~h}$ vs. $12 \mathrm{~h}, \mathrm{P}=0.002 ; 12 \mathrm{~h}$ vs. $48 \mathrm{~h}, \mathrm{P}=0.014$. For the comparison of the $\mathrm{ACTH}$ data between temperatures and times: $\mathrm{F}(6,230)=2.612$, $\mathrm{P}=0.019$. (B) For the comparison of the EPI data among multiple times: $\mathrm{F}(3,215)=4.229, \mathrm{P}=0.006 ; 1 \mathrm{~h}$ vs. $12 \mathrm{~h}, \mathrm{P}=0.005 ; 12 \mathrm{~h}$ vs. $24 \mathrm{~h}, \mathrm{P}=0.034$. For the comparison of the EPI data between temperatures and times: $F(6,215)=3.759, P=0.002$. (C) For the comparison of the ANG-II data among multiple times: $F(3,213)=3.181, P=0.025 ; 1 \mathrm{~h}$ vs. $24 \mathrm{~h}, \mathrm{P}=0.004 ; 24 \mathrm{~h}$ vs. $48 \mathrm{~h}, \mathrm{P}=0.046$. For the comparison of the ANG-II data between temperatures and times: $\mathrm{F}(6,213)=5.103$, $\mathrm{P}<0.001$. For the comparison of the ANG-II data between times and stimulants: F $(6,213)=2.297$, P=0.037. ACTH, adrenocorticotropin; EPI, epinephrine; ANG-II, angiotensin-II; LPS, lipopolysaccharide; Con-A, concanavalin A.

observed at 1,24 and $48 \mathrm{~h}$ at $4^{\circ} \mathrm{C}$ and at the 1-48-h time-points at $-12^{\circ} \mathrm{C}$ in the non-stimulation, LPS-stimulation and Con-A-stimulation groups, particularly at $-12^{\circ} \mathrm{C}$ (Figs. $5 \mathrm{E}$ and $\mathrm{F}$ and $6 \mathrm{C}$ ). Greater temperature decreases resulted in more marked decreases in the percentage of $\mathrm{CD} 4^{+} \mathrm{CD} 25^{+} \mathrm{Foxp} 3^{+}$ Treg cells.

To the best of our knowledge, the results of the present study have demonstrated for the first time that the percentage of $\mathrm{CD} 4^{+} \mathrm{CD} 25^{+} \mathrm{Foxp} 3^{+}$Treg cells was significantly decreased in the rat peripheral blood following cold stress, which suggests that the adaptive immunity and immunoregulation of rats are disturbed by cold stress. In a previous study by Kelley et al (6), it was shown that cold exposure increased the DTH reaction by $42 \%$ in calves.

\section{Discussion}

It has been shown in a number of studies that the HPA axis, AHS and RAAS are activated in animals exposed to cold stress (8-12); however, T-helper 1 (Th1) cytokine (INF- $\gamma$ ) production is suppressed in animals exposed to cold stress $(11,15)$. In experimental autoimmune encephalomyelitis mice, inflammatory foci of the central nervous system were decreased and splenic $\mathrm{CD} 4{ }^{+} \mathrm{CD} 25^{+} \mathrm{Foxp} 3^{+}$Treg cells were 
A

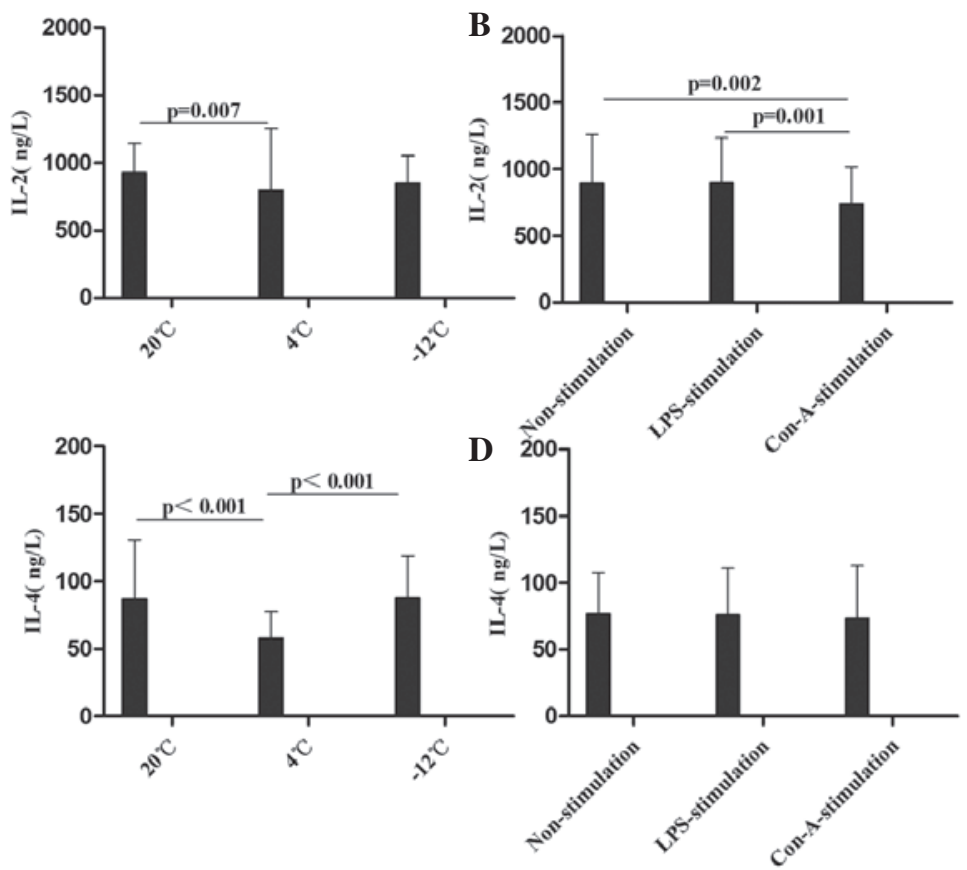

$\mathbf{E}$

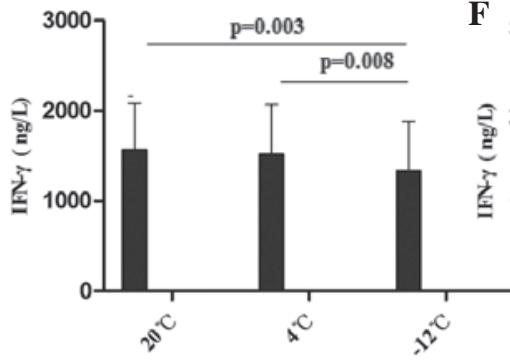

${ }^{3000}{ }^{300} \quad{ }_{\mathrm{p}=0.032}$

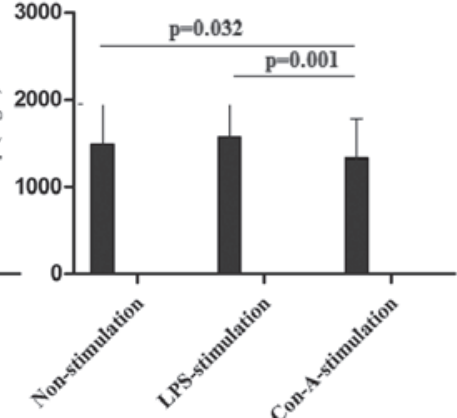

G

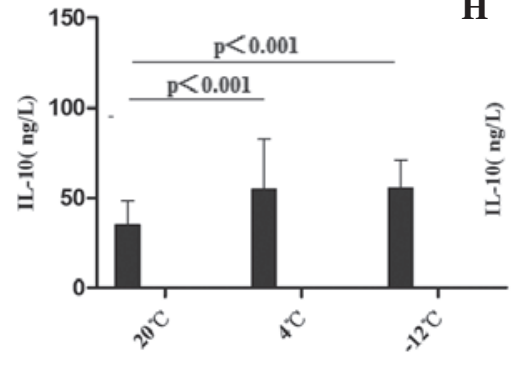

H

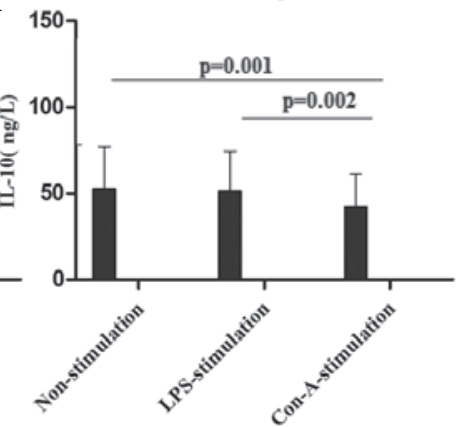

Figure 3. Comparison of the mean levels of (A and B) IL-2, (C and D) IL-4, (E and F) IFN- $\gamma$ and (G and H) IL-10 in the plasma at different temperatures and with different stimulants. Data are presented in $n g / 1$ as the mean \pm standard deviation. (A and B) Analysis of the IL-2 data revealed the following: Comparison among multiple temperatures, $\mathrm{F}(2,229)=5.323, \mathrm{P}=0.006$; comparison among multiple stimulants: $\mathrm{F}(2,229)=4.603$, $\mathrm{P}=0.011$; comparison between temperatures and stimulants, $\mathrm{F}(4,229)=7.796, \mathrm{P}<0.001$. (C and D) Analysis of the IL-4 data revealed the following: Comparison among multiple temperatures, $\mathrm{F}(2,228)=33.255, \mathrm{P}<0.001$. ( $\mathrm{E}$ and $\mathrm{F})$ Analysis of the IFN $\gamma$ data revealed the following: Comparison among multiple temperatures: $\mathrm{F}(2,229)=3.624, \mathrm{P}=0.029$; comparison among multiple stimulants: $\mathrm{F}(2,229)=4.242, \mathrm{P}=0.016$. $(\mathrm{G}$ and $\mathrm{H})$ Analysis of the IL-10 data revealed the following: Comparison among multiple temperatures: $\mathrm{F}(2,230)=27.150, \mathrm{P}<0.001$; comparison among multiple stimulants: $\mathrm{F}(2,230)=4.732, \mathrm{P}=0.010$; comparison between temperatures and stimulants: $\mathrm{F}(4,230)=5.710, \mathrm{P}<0.001$. IL, interleukin; IFN- $\gamma$, interferon- $\gamma$; LPS, lipopolysaccharide; Con-A, concanavalin A.

doubled following ACTH oral administration (16). ANG-II caused a $43 \%$ decrease in the number of Foxp $3^{+}$cells in the renal cortex compared with the control (17). The present study also demonstrated that ACTH, EPI and ANG-II levels were increased in rats following cold stress, which suggests that cold stress excites the HPA axis, the AHS and the RAAS, which may be a cause of immune disorders in rats suddenly exposed to the cold.
The TLR4 expressed on immunocompetent cells not only participates in phagocytizing bacteria, viruses and protozoans as part of the innate immunity to protect the body, but also mediates the maturation and activation of antigen-presenting cells and the proliferation, differentiation and development of $\mathrm{T}$ and B lymphocytes $(18,19)$ as part of the adaptive immune response to protect the body. Du et al (20) demonstrated that the stress hormone EPI 
A

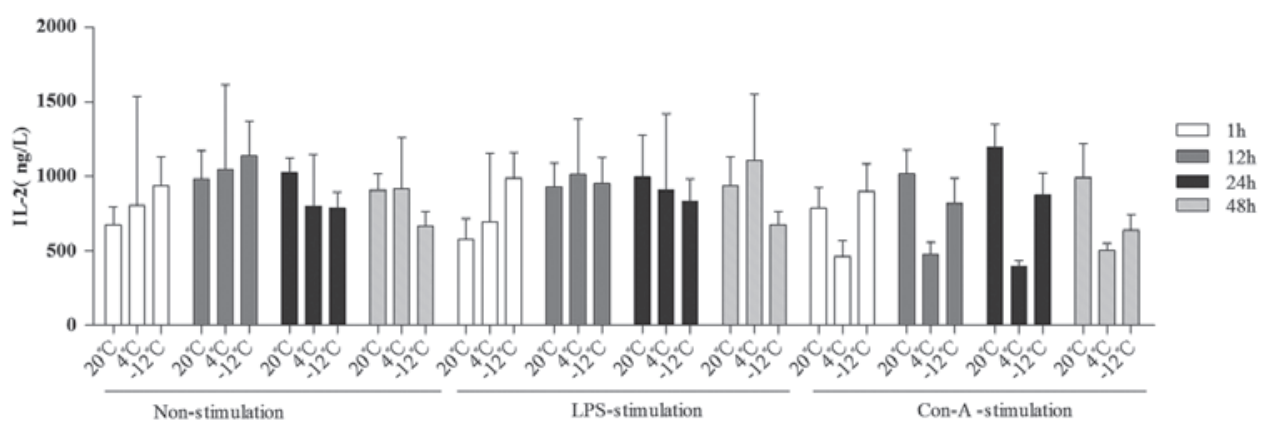

B

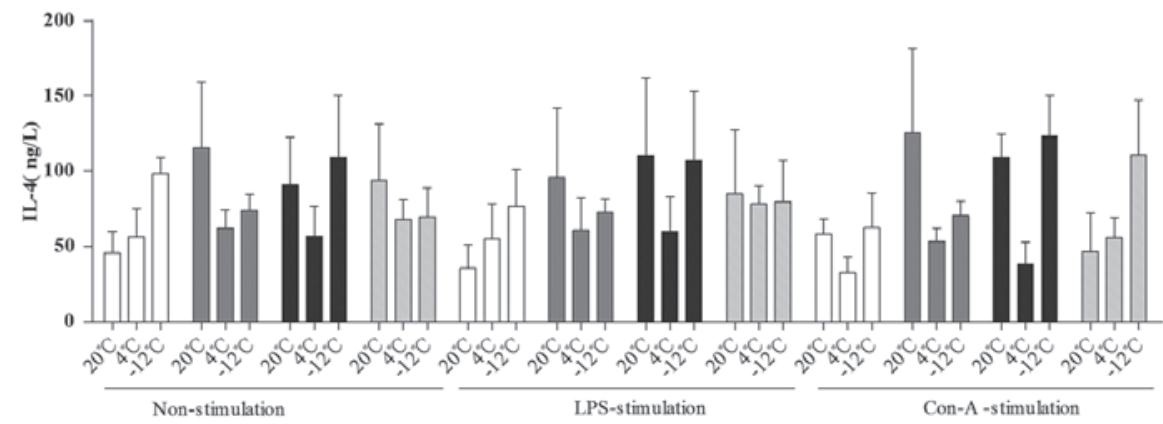

C

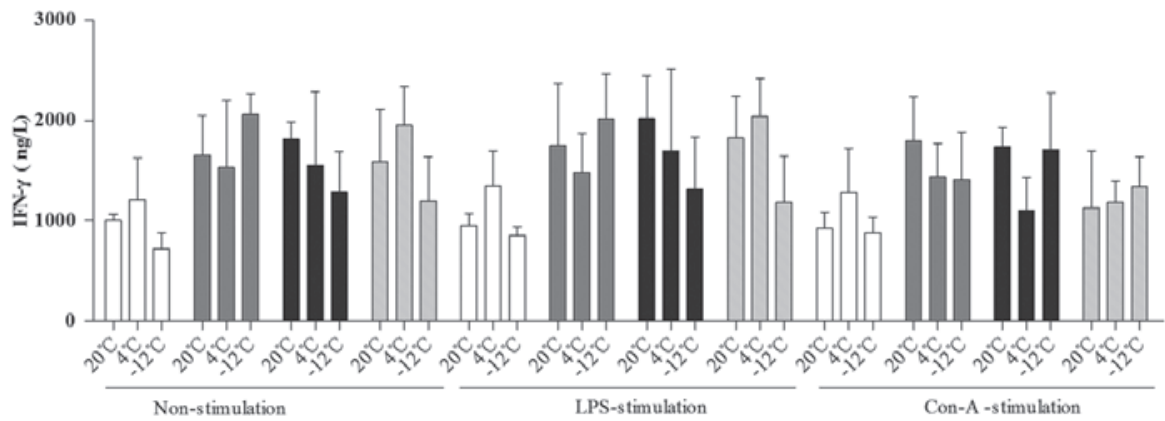

D

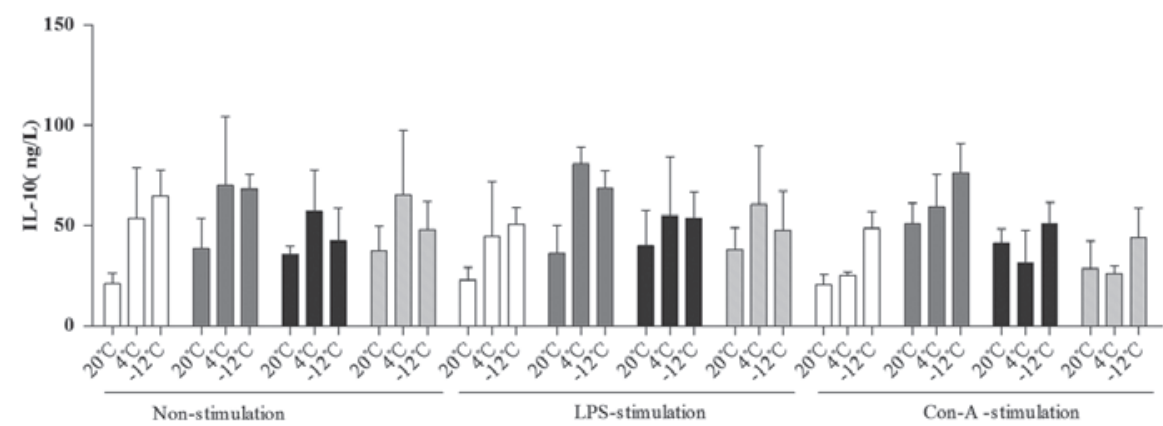

Figure 4. Comparison of the mean levels of (A) IL-2, (B) IL-4, (C) IFN- $\gamma$ and (D) IL-10 in the plasma at different times, temperatures and with different stimulants. Data are presented in $\mathrm{ng} / \mathrm{l}$ as the mean \pm standard deviation. (A) For the comparison of the IL-2 data among multiple times: F (3,229) $=3.208$, $\mathrm{P}=0.024 ; 1 \mathrm{~h}$ vs. $12 \mathrm{~h}, \mathrm{P}=0.003$. For the comparison of the IL-2 data between temperatures and times: $\mathrm{F}(6,229)=3.979$, $\mathrm{P}=0.001$. (B) For the comparison of the IL-4 data among multiple times: $\mathrm{F}(3,228)=12.828, \mathrm{P}<0.001 ; 1 \mathrm{~h}$ vs. $12 \mathrm{~h}, \mathrm{P}<0.001 ; 1 \mathrm{~h}$ vs. 24 h, $\mathrm{P}<0.001 ; 1$ h vs. 48 h, $\mathrm{P}=0.001 ; 24$ h vs. 48 h, $\mathrm{P}=0.044$. For the comparison of the IL-4 data between temperatures and times: F $(6,228)=9.068, \mathrm{P}<0.001$. For the comparison of the IL- 4 data among temperatures, times and stimulants: $\mathrm{F}(12,228)=2.130, \mathrm{P}=0.017$. (C) For the comparison of the IFN $\gamma$ data among multiple times: $\mathrm{F}(3,229)=22.894, \mathrm{P}<0.001 ; 1 \mathrm{~h}$ vs. $12 \mathrm{~h}, \mathrm{P}<0.001$; $1 \mathrm{~h}$ vs. $24 \mathrm{~h}, \mathrm{P}<0.001 ; 1 \mathrm{~h}$ vs. 48 h, $\mathrm{P}<0.001$. For the comparison of the IFN- $\gamma$ data between temperatures and times: $\mathrm{F}(6,230)=5.445$, $\mathrm{P}<0.001$. (D) For the comparison of the IL-10 data among multiple times: $\mathrm{F}(3,230)=15.342, \mathrm{P}<0.001 ; 1 \mathrm{~h}$ vs. $12 \mathrm{~h}, \mathrm{P}<0.001 ; 1 \mathrm{~h}$ vs. $24 \mathrm{~h}, \mathrm{P}<0.001 ; 12 \mathrm{~h}$ vs. $24 \mathrm{~h}, \mathrm{P}<0.001 ; 12 \mathrm{~h}$ vs. $48 \mathrm{~h}, \mathrm{P}<0.001$. For the comparison of the IL-10 data between temperatures and times: $\mathrm{F}(6,230)=2.326, \mathrm{P}=0.034$. IL, interleukin; IFN- $\gamma$, interferon- $\gamma$; LPS, lipopolysaccharide; Con-A, concanavalin A.

downregulated TLR4 mRNA expression in macrophages in a time- and dose-dependent manner. In the present study, a reduction in the TLR $4^{+} \mathrm{MNC}$ rates in the spleen in rats exposed to cold stress was observed. These findings suggest that innate immunosuppression may be due to an increase in stress hormones and a decrease in the TLR4 expression of immunocompetent cells in rats exposed to the cold. These data are consistent with the observed sudden increase in the morbidity of upper respiratory tract infections following sudden environmental temperature decreases (1). 
A

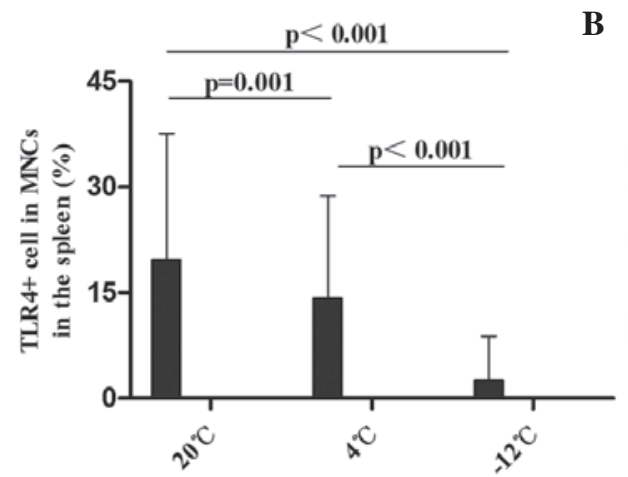

C

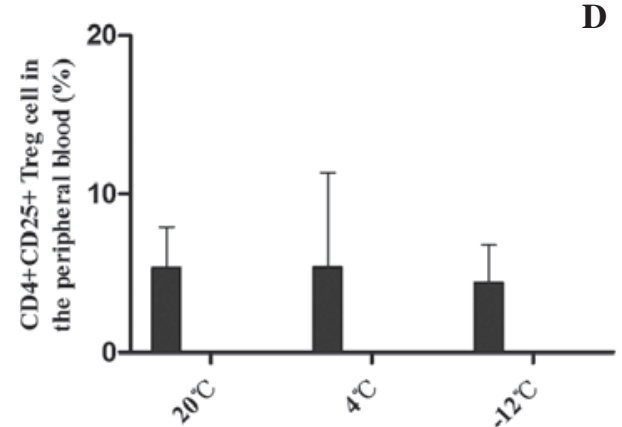

$\mathbf{E}$

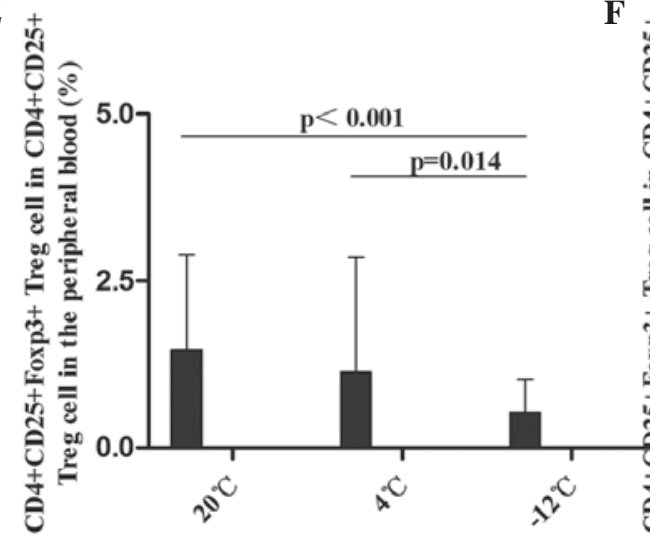

B

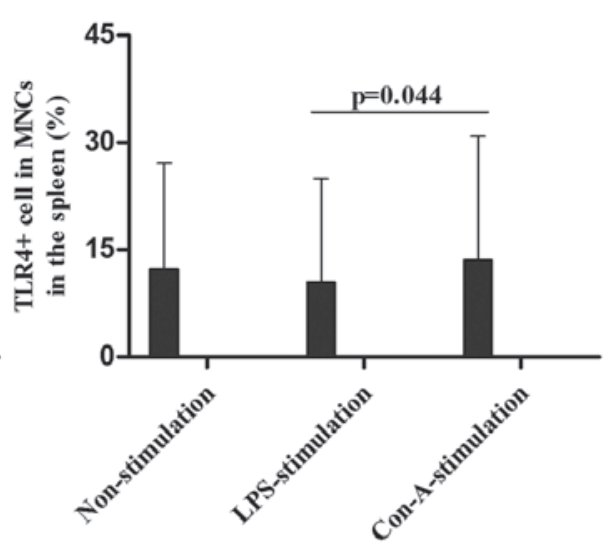

D
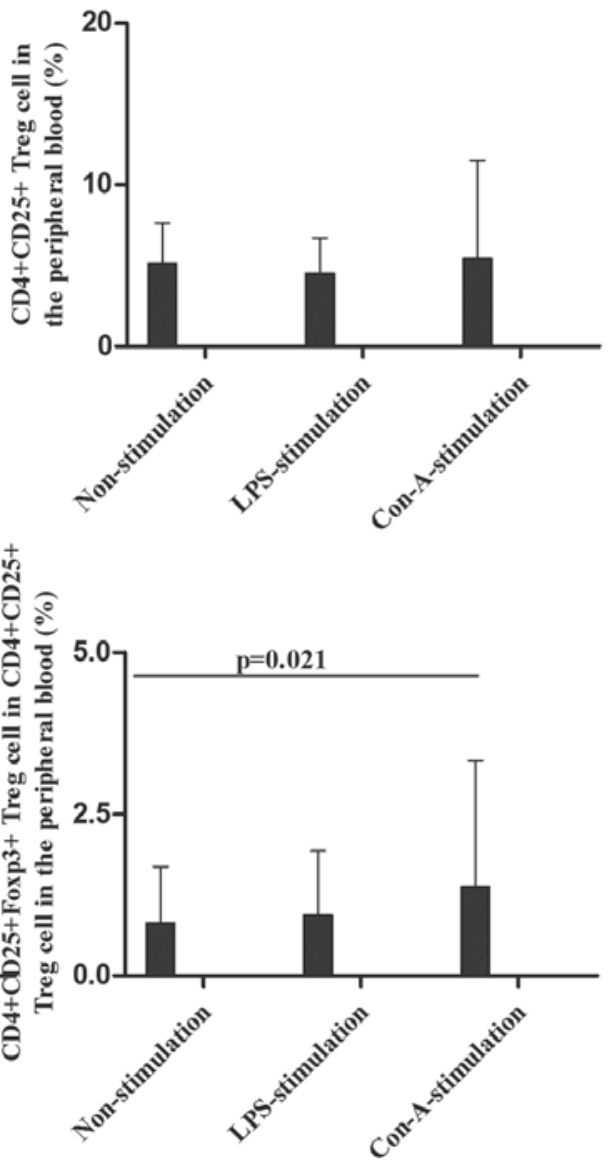

Figure 5. Comparison of the mean levels of (A and B) TLR4 $4^{+} \mathrm{MNCs}$ in the spleen, $\left(\mathrm{C}\right.$ and D) $\mathrm{CD} 4{ }^{+} \mathrm{CD} 25^{+}$Treg cells and $(\mathrm{E}$ and $\mathrm{F}) \mathrm{CD}^{+} \mathrm{CD} 25^{+} \mathrm{Foxp} 3^{+} \mathrm{Treg}$ cells in the peripheral blood at different temperatures and with different stimulants. Data (\%) are presented as the mean \pm standard deviation. (A and B) Analysis of the TLR4 ${ }^{+}$MNC data revealed the following: Comparison among multiple temperatures, $\mathrm{F}(2,108)=67.199, \mathrm{P}<0.001$; comparison among multiple stimulants, $\mathrm{F}(2,108)=2.129, \mathrm{P}=0.126$; LPS vs. Con- $\mathrm{A}, \mathrm{P}=0.044$. ( $\mathrm{C}$ and $\mathrm{D})$ Analysis of the $\mathrm{CD} 4{ }^{+} \mathrm{CD} 25^{+}$Treg cell data revealed the following: Comparison among multiple temperatures, $\mathrm{F}(2,108)=0.754, \mathrm{P}=0.474$; comparison among multiple stimulants, $\mathrm{F}(2,108)=0.532, \mathrm{P}=0.589$. $(\mathrm{E}$ and $\mathrm{F})$ Analysis of the $\mathrm{CD} 4^{+} \mathrm{CD} 25^{+} \mathrm{Foxp} 3^{+}$ Treg cell data revealed the following: Comparison among multiple temperatures, $\mathrm{F}(2,108)=7.984, \mathrm{P}=0.001$; comparison between temperatures and stimulants, $\mathrm{F}(4,108)=1.907, \mathrm{P}=0.118$; comparison between $20^{\circ} \mathrm{C}$ and $-12^{\circ} \mathrm{C}, \mathrm{P}<0.001$; comparison between $4^{\circ} \mathrm{C}$ and $-12^{\circ} \mathrm{C}, \mathrm{P}=0.014$. TLR, Toll-like receptor 4; $\mathrm{CD}$, cluster of differentiation; Foxp3, Forkhead box P3; MNC, mononuclear cell; Treg, regulatory T; LPS, lipopolysaccharide; Con-A, concanavalin A.

It has been found in previous studies that the IL-2 level was decreased, even following Con-A and LPS stimulation, and the corticosterone level was increased in rats exposed to acute and chronic cold stress $(7,13)$. In addition, mice subjected to cold stress exhibited decreased IL-4 and IFN- $\gamma$ production and an increased IL-10 level $(9,14)$. The results of the present study also demonstrated that the levels of IL-2, IL-4 and IFN- $\gamma$ were decreased and that the level of
IL-10 was increased in rats exposed to cold stress, even with LPS and Con-A stimulation, compared with the findings at $20^{\circ} \mathrm{C}$. These results suggest that cold stress not only excites ACTH, EPI and ANG-II production, but also alters the balance of immunity and decreases the innate and adaptive immunity in rats. Previous studies have found that ACTH inhibits Con-A-stimulated T-lymphocyte mitogenesis (21) and decreases IL-2 and IFN- $\gamma$ production in mice (16). 


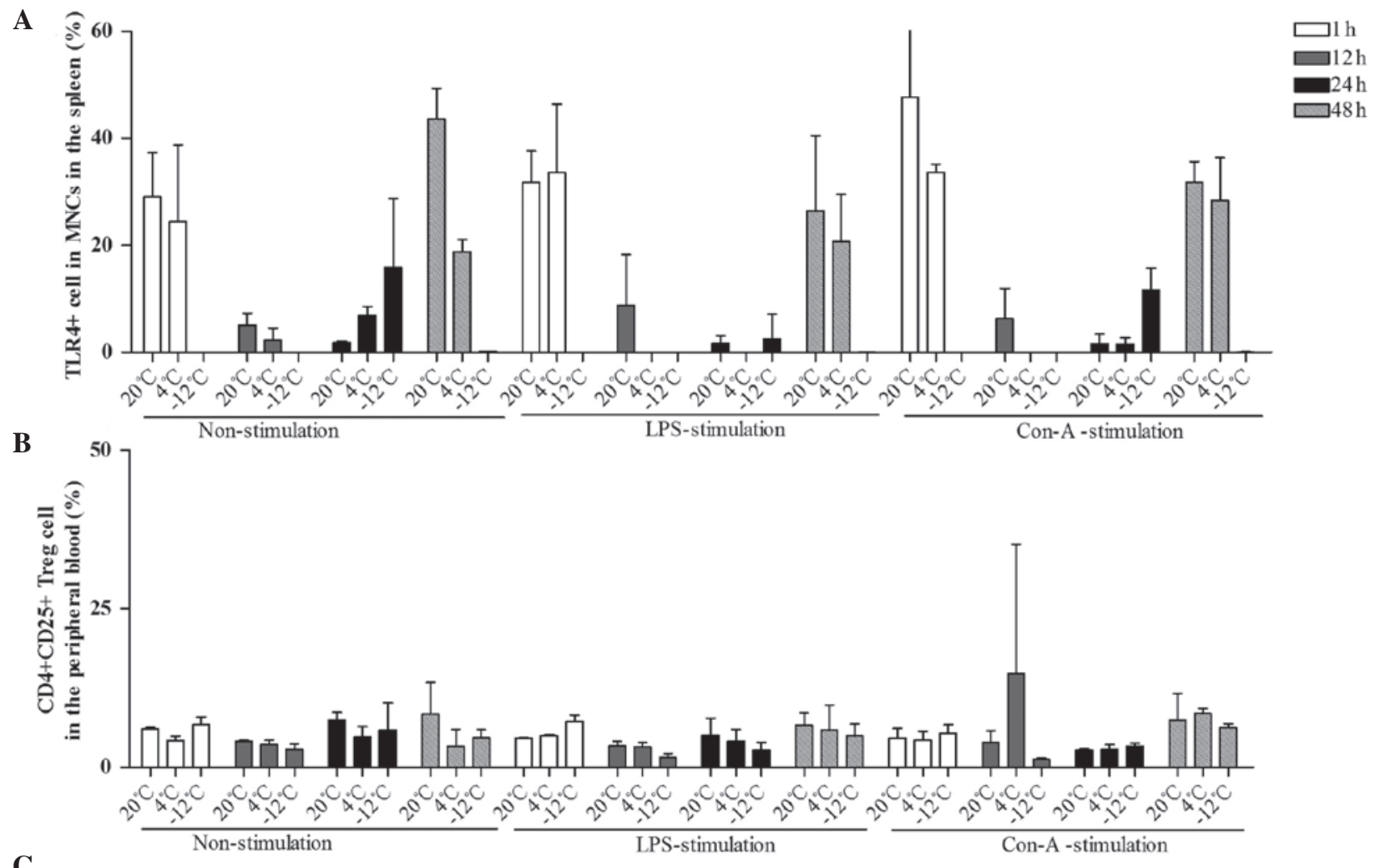

C

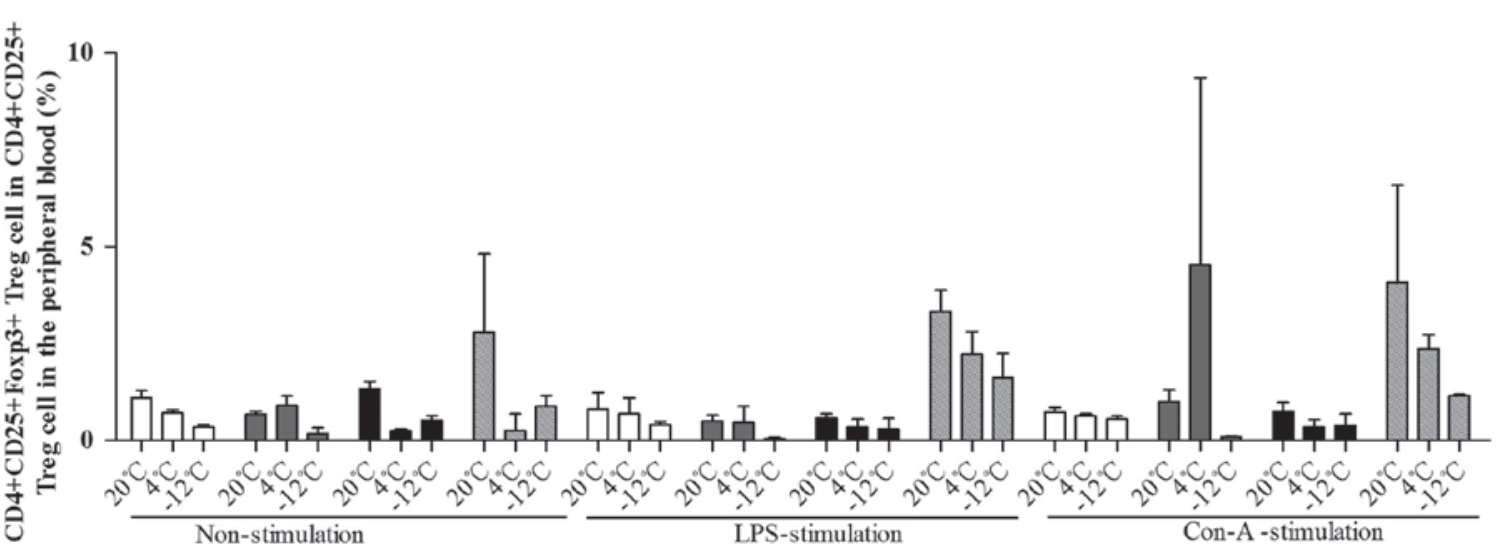

Figure 6. Comparison of the mean levels of (A) TLR $4^{+} \mathrm{MNCs}$ in the spleen, (B) $\mathrm{CD} 4^{+} \mathrm{CD} 25^{+}$Treg cells and (C) $\mathrm{CD} 4^{+} \mathrm{CD} 25^{+} \mathrm{Foxp} 3^{+}$Treg cells in the peripheral blood at different times, temperatures and with different stimulants. Data (\%) are presented as the mean \pm standard deviation. (A) For the comparison of the TLR4 ${ }^{+}$data among multiple times: $\mathrm{F}(3,108)=64.432$, $\mathrm{P}<0.001 ; 1 \mathrm{~h}$ vs. $12 \mathrm{~h}, \mathrm{P}<0.001 ; 1 \mathrm{~h}$ vs. $24 \mathrm{~h}, \mathrm{P}<0.001 ; 12 \mathrm{~h}$ vs. 48 h, $\mathrm{P}<0.001 ; 24$ h vs. 48 h, $\mathrm{P}<0.001$. For the comparison of the TLR $4^{+}$data between temperatures and times: $\mathrm{F}(6,108)=29.595, \mathrm{P}<0.001$. For the comparison of the TLR $4^{+}$data between times and stimulants: $\mathrm{F}(6,108)=2.281, \mathrm{P}=0.045$. For the comparison of the TLR4 ${ }^{+}$data among temperatures, times and stimulants: $\mathrm{F}(12,228)=1.954, \mathrm{P}=0.042$. (B) For the comparison of the $\mathrm{CD} 4{ }^{+} \mathrm{CD} 25^{+}$Treg data among multiple times: $\mathrm{F}(3,108)=1.568, \mathrm{P}=0.205$. (C) For the comparison of the $\mathrm{CD} 4{ }^{+} \mathrm{CD} 25^{+} \mathrm{Foxp} 3^{+}$ Treg cell data among multiple times: $\mathrm{F}(3,108)=13.322, \mathrm{P}<0.001 ; 1 \mathrm{~h}$ vs. $48 \mathrm{~h}, \mathrm{P}<0.001 ; 12 \mathrm{~h}$ vs. $48 \mathrm{~h}, \mathrm{P}<0.001 ; 24 \mathrm{~h}$ vs. $48 \mathrm{~h}, \mathrm{P}<0.001$. For the comparison of the $\mathrm{CD} 4{ }^{+} \mathrm{CD} 25^{+} \mathrm{Foxp}^{+}$Treg cell data between temperatures and times: $\mathrm{F}(6,108)=4.434, \mathrm{P}=0.001$. For the comparison of the $\mathrm{CD}^{+} \mathrm{CD} 25^{+} \mathrm{Foxp} 3^{+} \mathrm{Treg}$ cell data between times and stimulants: F $(6,108)=2.397, \mathrm{P}=0.036)$. TLR, Toll-like receptor 4; CD, cluster of differentiation; Foxp3, Forkhead box P3; MNC, mononuclear cell; Treg, regulatory T; LPS, lipopolysaccharide; Con-A, concanavalin A.

Furthermore, EPI potently stimulates IL-10 production (22), and IL-10 has been shown to enhance corticotropin-releasing factor and $\mathrm{ACTH}$ production in hypothalamic and pituitary tissues (23).

Cold stress affects the host adaptive immune system. Kelley et al (6) demonstrated that cold exposure increased the DTH reaction by $42 \%$ in calves, which suggests that the immunosuppression ability declines when calves are exposed to cold stress. Foxp 3 expressed on $\mathrm{CD} 4{ }^{+} \mathrm{CD} 25^{+}$Treg cells is an important marker of suppressive Treg cells (24). Although ACTH signifi- cantly decreases $\mathrm{CD} 4^{+} \mathrm{T}$-cell counts, immunoglobulin levels did not change. In a previous study, the splenic $\mathrm{CD} 4^{+} \mathrm{CD} 25^{+} \mathrm{Foxp} 3^{+}$ Treg frequency doubled in mice fed with ACTH compared with control mice (16). Blocking ANG-II production with angiotensin-converting enzyme inhibitors or inhibiting ANG-II signaling with AT(1) receptor blockers suppressed autoreactive Th1 and Th17 cells and promoted antigen-specific CD $4^{+} \mathrm{Foxp}^{+}$ Treg cell production (25). In the present study it was demonstrated that the percentage of $\mathrm{CD} 4^{+} \mathrm{CD} 25^{+} \mathrm{Foxp} 3^{+}$Treg cells was significantly decreased following cold stress, and that greater 
temperature decreases resulted in more evident decreases in the percentage of $\mathrm{CD} 4^{+} \mathrm{CD} 25^{+} \mathrm{Foxp} 3^{+}$Treg cells, which suggests that sudden cold stress facilitates the development and occurrence of autoimmune disease.

\section{Acknowledgements}

This study was supported by grants from the 'Eleventh Five-year Plan' and support plans of the National Ministry of Science and Technology (no. 2008 Bai68b01).

\section{References}

1. Smith AP: Effects of upper respiratory tract illnesses and stress on alertness and reaction time. Psychoneuroendocrinology 38: 2003-2009, 2013.

2. Temajo NO and Howard N: The mosaic of environment involvement in autoimmunity: the abrogation of viral latency by stress, a non-infectious environmental agent, is an intrinsic prerequisite prelude before viruses can rank as infectious environmental agents that trigger autoimmune diseases. Autoimmun Rev 13: 635-640, 2014.

3. Baccan GC, Oliveira RD and Mantovani B: Stress and immunological phagocytosis: possible nongenomic action of corticosterone. Life Sci 75: 1357-1368, 2004

4. Branger J, Leemans JC, Florquin S, Weijer S, Speelman P and Van Der Poll T: Toll-like receptor 4 plays a protective role in pulmonary tuberculosis in mice. Int Immunol 16: 509-516, 2004.

5. Zieziulewicz TJ, Mondal TK, Gao D and Lawrence DA: Stress-induced effects, which inhibit host defenses, alter leukocyte trafficking. Cell Stress Chaperones 18: 279-291, 2013.

6. Kelley KW, Greenfield RE, Evermann JF, Parish SM and Perryman LE: Delayed-type hypersensitivity, contact sensitivity, and phytohemagglutinin skin-test responses of heat- and cold-stressed calves. Am J Vet Res 43: 775-779, 1982.

7. Liu YL, Bi H, Chi SM, Fan R, Wang YM, Ma XL, Chen YM, Luo WJ, Pei JM and Chen JY: The effect of compound nutrients on stress-induced changes in serum IL-2, IL-6 and TNF-alpha levels in rats. Cytokine 37: 14-21, 2007.

8. Ablimit A, Kühnel H, Strasser A and Upur H: Abnormal Savda syndrome: long-term consequences of emotional and physical stress on endocrine and immune activities in an animal model. Chin J Integr Med 19: 603-609, 2013.

9. Belay T and Woart A: Cold-induced stress increases the intensity of Chlamydia genital infection in mice. J Microbiol Immunol Infect 46: 330-337, 2013.

10. Vernikos J, Dallman MF, Bonner C, Katzen A and Shinsako J: Pituitary-adrenal function in rats chronically exposed to cold Endocrinology 110: 413-420, 1982.
11. Yang G, Xi ZX, Wan Y, Wang H and Bi G: Changes in circulating and tissue angiotensin II during acute and chronic stress. Biol Signals 2: 166-172, 1993.

12. Israel A, Zavala LE, Cierco M, Gutierrez A and Garrido Mdel R: Effect of AT(1) angiotensin II receptor antagonists on the sympathetic response to a cold pressor test in healthy volunteers. Am J Ther 14: 183-188, 2007.

13. Shu J, Stevenson JR and Zhou X: Modulation of cellular immune responses by cold water swim stress in the rat. Dev Comp Immunol 17: 357-371, 1993.

14. Aviles H and Monroy FP: Immunomodulatory effects of cold stress on mice infected intraperitoneally with a $50 \%$ lethal dose of Toxoplasma gondii. Neuroimmunomodulation 9: 6-12, 2001.

15. Goldstein DS and Kopin IJ: Adrenomedullary, adrenocortical, and sympathoneural responses to stressors: a meta-analysis. Endocr Regul 42: 111-119, 2008.

16. Brod SA and Hood ZM: Ingested (oral) ACTH inhibits EAE. J Neuroimmunol 232: 131-135, 2011.

17. Barhoumi T Kasal DA, Li MW, Shbat L, Laurant P, Neves MF, Paradis P and Schiffrin EL: T regulatory lymphocytes prevent angiotensin II-induced hypertension and vascular injury. Hypertension 57: 469-476, 2011.

18. Dabbagh K, Dahl ME, Stepick-Biek P and Lewis DB: Toll-like receptor 4 is required for optimal development of Th2 immune responses: role of dendritic cells. J Immunol 168: 4524-4530, 2002.

19. Hayashi EA, Akira S and Nobrega A: Role of TLR in B cell development: signaling through TLR4 promotes B cell maturation and is inhibited by TLR2. J Immunol 174: 6639-6647, 2005.

20. Du Q, Min S, Chen LY, Ma YD, Guo XL, Wang Z and Wang ZG: Major stress hormones suppress the response of macrophages through down-regulation of TLR2 and TLR4. J Surg Res 173: 354-361, 2012.

21. Johnson EW, Hughes TK Jr and Smith EM: ACTH enhancement of T-lymphocyte cytotoxic responses. Cell Mol Neurobiol 25: 743-757, 2005.

22. Smith EM, Cadet P, Stefano GB, Opp MR and Hughes TK Jr: IL-10 as a mediator in the HPA axis and brain. J Neuroimmunol 100: 140-148, 1999.

23. Elenkov IJ, Kvetnansky R, Hashiramoto A, Bakalov VK, Link AA, Zachman K, Crane M, Jezova D, Rovensky J, Dimitrov MA, Gold PW, Bonini S, Fleisher T, Chrousos GP and Wilder RL: Low- versus high-baseline epinephrine output shapes opposite innate cytokine profiles: presence of Lewis- and Fischer-like neurohormonal immune phenotypes in humans? J Immunol 181: 1737-1745, 2008.

24. Kim JM and Rudensky A: The role of the transcription factor Foxp3 in the development of regulatory $\mathrm{T}$ cells. Immunol Rev 212: 86-98, 2006

25. Platten M, Youssef S, Hur EM, Ho PP, Han MH, Lanz TV, Phillips LK, Goldstein MJ, Bhat R, Raine CS, Sobel RA and Steinman L: Blocking angiotensin-converting enzyme induces potent regulatory T cells and modulates TH1- and TH17-mediated autoimmunity. Proc Natl Acad Sci USA 106: 14948-14953, 2009. 